\title{
OBITUARY
}

\section{SHELOMO DOV GOITEIN}

\author{
1900-1985
}

SHELOMO DOV GOITEIN, professor emeritus of Islamic Studies at the Hebrew University of Jerusalem, professor emeritus of Arabic at the University of Pennsylvania, long-term member of the School of Historical Studies at the Institute for Advanced Study in Princeton, and one of the three original honorary members of the Middle East Studies Association (along with Phillip K. Hitti and H. A. R. Gibb), died at his home in Princeton, New Jersey on 6 February 1985.

He was in his eighty-fifth year. Several months before his death he completed the final volume of his monumental study $A$ Mediterranean Society, and was already deeply involved on a projected three-volume work on the medieval India trade, based on Cairo Geniza documents of the eleventh through thirteenth century.

By virtue of his research, his writing, and his learning, Goitein ranked as one of the major scholars of Middle Eastern studies in our century.

Goitein was born on 4 April 1900 in the tiny Bavarian village of Burgkungstadt. His father, Dr. Eduard Goitein, who died when Shelomo was fourteen years old, was the district rabbi and the leader of the small local Jewish community. At age fourteen, Goitein left his birthplace to prepare his gymnasium and university studies at Frankfurt and Berlin, where he spent the following nine years, interrupted only by a three-month stint, in 1918, as an artillery lieutenant in the German army.

During these years (1914-23), he became deeply involved in Zionist and Jewish Youth organizations which combined nationalist ideals with those of personal perfection through communion with nature, music, and art. It was also during this period that he had frequent contact with such thinkers as Franz Rosenzweig and Martin Buber.

After completing his dissertation in 1923, he left Germany to settle in Palestine. In his early years in Palestine, he worked as a secondary school teacher in Haifa. Goitein frequently wrote and said that he saw himself primarily as an educator. Between 1938 and 1948 he resumed his involvement with secondary education when he served as His Majesty's Senior Education Officer in mandatory Palestine.

Shelomo Goitein was a member of the founding faculty of the Hebrew University of Jerusalem, where he inaugurated instruction in Islamic History and Islamic studies. He established its School of Oriental and African Studies and he was one of the founders of the Israel Oriental Society. It was in Jerusalem that he educated, trained, and raised up several gener- 
ations of distinguished Middle Eastern specialists such as David Ayalon, Joshua Blau, the late Gabriel Baer, the late Samuel Stern, Amnon Cohen, Emmanel Sivan, and many others.

In 1957, he accepted the invitation of the University of Pennsylvania to fill the chair of Arabic Studies at that university. Goitein's move from Jerusalem to Philadelphia coincided with the beginning of his deep research involvement with the Cairo Geniza documents and was motivated in large part by his conviction that this major scholarly project could be more effectively pursued in the relative tranquillity of an American University.

Upon his retirement from Pennsylvania in 1971, Goitein moved to Princeton, where he was appointed as a long-term member of the School of Historical Studies of the Institute for Advanced Studies, an appointment he held until his death. In the course of the last fifteen years, Goitein's singular contributions to scholarship were recognized by numerous awards, prizes, and honorary degrees. Among these were the Haskins Medal of the Medieval Academy of America (1970), the Giorgio Levi della Vida Prize for Distinguished Contributions to Islamic Studies (1975), the Harvey Prize (1980), and his appointment, in 1982, as a Lifetime Laureate of the MacArthur Foundation.

As of November 1984, Shelomo Goitein's bibliography numbers 599 items; when all the articles and books now in press are published, it will number well over 600 entries. He was a scholar, a man of letters, and an educator of great versatility. Among his earliest publications (1927) was a play called Pulcinella, a drama set in medieval France. As he himself confessed, it was his youthful ambition "to write for the stage in the morning and to study in the library in the afternoon. I forgot one important factor: the passion for knowledge." It was this passion for knowledge, its discovery and transmission, which decided his career as a scholar and educator. While he produced, as far as I know, no further plays, a pronounced æsthetic sensibility is present in all his scholarly writing and thinking.

His dissertation on "Prayer in the Qur'an" was completed at Frankfurt in 1923, but never published, owing to the disastrous deflation of the German currency in that year. Religion and religious institutions of both classical Islam and Judaism continued among his major interests, resulting in several important studies on prayer in Islam, the origins of Ramadan, and the nature of Muslim Friday worship. These studies are paralleled by numerous articles on Biblical themes, which appeared mostly, although not exclusively, in Hebrew.

Goitein took his role as an educator with utmost seriousness. A significant portion of his bibliography, especially in the 1940s and early 1950s, is devoted to pedagogical concerns. So, for example, in 1942 he published a volume in Hebrew entitled Bible Teaching in Public and Middle Schools: Aims, Methods, Syllabus, and in 1944 a book on the teaching of Hebrew 
in Palestinian schools as well as a two-part teaching anthology of modern Arabic literature.

During the 1930s, Goitein's two major research projects were the critical edition (at that time, on the basis of a unique manuscript) of Baladhuri's Ansāb al-ashrāf, and linguistic and socio-historical studies (including interviews and fieldwork) on Yemenite Jews. His edition of the fifth volume of Baladhuri's Ansāb, a work of model erudition, appeared in 1936. As a preparation for this work, Goitein immersed himself for several years in the study of the entire range of early Arabic literature. Thus, a side product of his work as a text-editor was a stream of articles on a wide variety of topics in early Islamic history and literature--on Mutanabbi, on ibn al-Muqaffa, on the origins of the vizierate, and on the birth-hour of Islamic law.

His Yemenite research was equally productive, resulting in four books (Jemenica, Sprichworter und Redensarten au Zentral-Jemen, Leipzig 1934; Von den Juden Jemens, eine Anthologie, Berlin 1934; the edition in San'ani Arabic of Hayyim Habshush's Ru'yat al-Yaman, an account of Joseph Halevy's travels in Yemen and Najran, published in 1940 and a Hebrew translation of this work published in 1939), and a large number of articles, including a lengthy study of the Arabic dialect of Lower Yemen, an ethnographic description and social analysis of a Jewish weaver's village in Yemen, and an essay on domestic architecture in San'a. Goitein regretted never having had the time to bring all his Yemenite research together in a comprehensive book on Yemenite Jews. However, he did acknowledge the great debt his late Geniza work owed to this early research. "I do not believe," he wrote in the preface to volume 2 of Mediterranean Society, "that I would have been able to understand these ancient parchments properly (I mean not only philologically, but also psychologically) had it not been for the many years of ethnolinguistic research I carried out among Yemenites, those most Jewish and most Arab of all Jews."

In his Geniza research, Goitein combined the most cherished concerns of his intellectual career. Upon his retirement from the University of Pennsylvania in 1970, he wrote that the dream of his youth was "on the one hand to interpret the classical sources of Judaism in the spirit of our time (as far as I understand it), and, on the other hand, to further the understanding of the world of Arabic Islam and its relationship to the Jewish people. The Geniza publications should contribute to both aims."

A Mediterranean Society: The Jewish Communities of the Arab World as Portrayed in the Documents of the Cairo Geniza. The title and subtitle Goitein gave to his six-volume magnum opus (volumes 5 and 6 will appear posthumously) epitomize his vision of Near Eastern history. From the very beginning of his Geniza work, he saw the communities which produced the Geniza documents as part and parcel of the culture and civilization in which they lived. He demonstrated that one could, without any hesitation, 
generalize the information garnered from these Judeo-Arabic documents to many aspects of the Islamic societies of North Africa, Egypt, and Palestine, and that the insights derived from medieval Islamic sources could equally illuminate the complexities of Jewish communal life and practice. Goitein universalized the Geniza. Through his research and writing, these fragments preserved in the lumber room of the synagogue at Fustat became a unique source not only for the history of the Jewish communities of the Arab world (as important as that is) but were transformed into the foundations for reconstructing the Mediterranean society of North Africa and Egypt between the eleventh and thirteenth centuries in a manner not previously possible.

To this vision of medieval Near Eastern history, Goitein brought the gifts of a highly skilful philologist and the refined sensitivity of a social and religious historian. He possessed an unmatched gift for recreating a whole society in all its vividness and on its many levels-economic, social, and individual-and in penetrating the soul and mentality of the people he was studying.

For the history of pre-modern Near Eastern societies, Goitein's achievement is of fundamental importance and as a contribution to history bears comparison to Fernand Braudel's magisterial work on the Mediterranean of the sixteenth and seventeenth centuries. Braudel's Mediterranean is vast, stretching from the Gates of Hercules to the gates of Peking, and it moves with the majestic, leisurely rhythms of the long durée. Goitein's Mediterranean is more modest. It includes only the coast between Tunisia and Egypt with small extensions in either direction; but it is teeming with people, not only with their partnerships and their quarrels, their wedding-contracts, dowries, house furnishings and tableware, but also with their mentality, their religion, and their most intimate feelings. The world Goitein recreated was not on the measure of the sea. Goitein's, like Braudel's, is a total history, but a total history on the scale of man.

Goitein lived his life according to his own deeply held precepts. In April 1970, he concluded his remarks to his colleagues at the University of Pennsylvania as follows: "Ecclesiastes has said: "in the morning sow your seed and in the evening do not let rest your hands.' Even in the evening of our lives we should not stop sowing. One day the seed might bring forth fruit." In the case of Shelomo Dov Goitein this wish will certainly be fulfilled.

\section{A. L. UdOVITCH Princeton University}

